\title{
SOIL FUNGISTASIS AGAINST Fusarium graminearum UNDER DIFFERENT CROP MANAGEMENT SYSTEMS
}

\author{
Bruno Brito Lisboa(1), Cimélio Bayer(2), Luciane Maria Pereira Passaglia(3), Flávio Anastácio de \\ Oliveira Camargo(2), Anelise Beneduzi(1), Adriana Ambrosini(2) and Luciano Kayser Vargas(1)*
}

(1) Fundação Estadual de Pesquisa Agropecuária, Porto Alegre, Rio Grande do Sul, Brasil.

(2) Universidade Federal do Rio Grande do Sul, Departamento de Ciência do Solo, Porto Alegre, Rio Grande do Sul, Brasil.

(3) Universidade Federal do Rio Grande do Sul, Departamento de Genética, Porto Alegre, Rio Grande do Sul, Brasil.

* Corresponding author.

E-mail: luciano-kayser@fepagro.rs.gov.br

\begin{abstract}
Soil management, in terms of tillage and cropping systems, strongly influences the biological properties of soil involved in the suppression of plant diseases. Fungistasis mediated by soil microbiota is an important component of disease-suppressive soils. We evaluated the influence of different management systems on fungistasis against Fusarium graminearum, the relationship of fungistasis to the bacterial profile of the soil, and the possible mechanisms involved in this process. Samples were taken from a long-term experiment set up in a Paleudult soil under conventional tillage or no-tillage management and three cropping systems: black oat (Avena strigose L.) + vetch (Vicia sativa L.)/maize (Zea mays L.) + cowpea (Vigna sinensis L.), black oat/maize, and vetch/maize. Soil fungistasis was evaluated in terms of reduction of radial growth of $F$. graminearum, and bacterial diversity was assessed using ribosomal intergenic spacer analysis (RISA). A total of 120 bacterial isolates were obtained and evaluated for antibiosis, and production of volatile compounds and siderophores. No-tillage soil samples showed the highest level of $F$. graminearum fungistasis by sharply reducing the development of this pathogen. Of the cropping systems tested, the vetch + black oat/maize + cowpea system showed the highest fungistasis and the oat/maize system showed the lowest. The management system also affected the genetic profile of the bacteria isolated, with the systems from fungistatic soils showing greater similarity. Although there was no clear relationship between soil management and the characteristics of the bacterial isolates, we may conclude that antibiosis and the production of siderophores were the main mechanisms accounting for fungistasis.
\end{abstract}

Keywords: crop systems, fungistasis, no-tillage, plant diseases. 


\title{
RESUMO: FUNGISTASE A Fusarium graminearum DE UM SOLO SUBMETIDO A DIFERENTES SISTEMAS DE MANEJO
}

\begin{abstract}
O manejo, em termos de preparo e sistemas de culturas, exerce forte influência sobre as propriedades do solo; e essas, por sua vez, condicionam o seu potencial supressivo a doenças de plantas. Nesse contexto, a fungistase é um dos componentes da supressividade, sendo um processo mediado pela microbiota do solo. Este trabalho teve como objetivo avaliar a influência de diferentes sistemas de manejo sobre a fungistase ao fungo fitopatogênico Fusarium graminearum, a sua relação com o perfil bacteriano do solo e os possiveis mecanismos de ação envolvidos no processo. As avaliações foram realizadas a partir de amostras de um Argissolo Vermelho distrófico, coletadas em um experimento de manejo de longa duração, conduzido sob plantio direto e preparo convencional e cultivado com os sistemas de culturas aveia + vica/milho + caupi, vica/milho e aveia/milho. A fungistase do solo foi avaliada em termos de redução do crescimento radial do fungo testado. O perfil bacteriano foi avaliado pelo polimorfismo do espaço intergênico do $16 \mathrm{~S}$ rRNA (RISA). Foram obtidos 120 isolados bacterianos, que foram avaliados quanto à antibiose e à produção de compostos voláteis e de sideróforos. As amostras provenientes de plantio direto apresentaram maior fungistase a F. graminearum, reduzindo acentuadamente o desenvolvimento do patógeno. Também foi observada maior inibição do patógeno nas amostras de solo cultivadas sob o sistema aveia + vica / milho + caupi, enquanto o sistema aveia/milho foi o menos antagonista. O perfil genético bacteriano do solo também foi influenciado pelos sistemas de manejo, havendo semelhança entre os sistemas mais antagonistas. Embora não tenha sido identificada uma relação entre os sistemas de manejo e as características dos isolados, pode-se concluir que a antibiose e a produção de sideróforos foram os mecanismos que mais contribuíram para a fungistase.
\end{abstract}

Palavras-chave: sistemas de cultivo, fusariose, plantio direto, doenças de planta.

\section{INTRODUCTION}

Soil-borne plant diseases cause significant crop damage, principally by attacking the root system of seedlings and adult plants. Many plant diseases are difficult to control using conventional methods, such as the adoption of resistant cultivars or the application of agrochemicals (Weller et al., 2002). The interaction between plant pathogens and other components of the soil microbial community is a factor in plant health, which is an important component of soil quality (Peters et al., 2003). Suppression of plant disease by soils is a well-documented phenomenon established in the 1970s by Baker and Cook (1974), who defined soil suppression as "the capacity of a soil to maintain a low incidence or severity of a specific plant disease even in the presence of the pathogen, susceptible plants and favorable environmental conditions for the development of the disease."

Reduction in the incidence of disease due to soil suppression is attributable to several factors, including induction of plant systemic resistance and direct inhibition of pathogens by the overall microbial activity of a soil (Weller et al., 2002). In this context, fungistasis can be defined in terms of soil suppression as the capacity of a soil to inhibit the germination of fungal spores and reduce the vegetative growth of phytopathogenic fungi (Garbeva et al., 2011). Fungistasis occurs through a variety of mechanisms linked to the microbial community of a soil, such as the production of antimicrobial compounds and competition for nutrients, especially Fe uptake mediated by siderophores (Hadar and Papadopoulou, 2012).
Agricultural soils are complex ecosystems, consisting of dynamic processes that can be modified by soil management techniques, such as soil tillage and cropping systems. Inadequate soil management techniques can degrade soils by affecting not only the physical properties of soil, e.g., soil loss and compaction, but also soil chemistry factors, such as nutrient leaching, and biological process, including increased pathogen activity (Jantalia et al., 2006). However, good management practices can lead to improvements in these properties (Bayer and Mielniczuk, 1997).

Soil management systems differ in relation to the degree of soil disturbance and the type of organic residues present in the soil. Conventional tillage mainly involves turning the soil by plowing and harrowing and the incorporation of plant residues, but it may lead to loss of soil structure and organic matter, as well as erosion of the soil surface and compaction below the plowed layer. The no-tillage system was developed to reduce the undesirable effects of conventional tillage by eliminating disturbance due to plowing; a further advantage of this system is that plant residues remain on the soil surface and help protect the soil from erosion (Derpsch et al., 2010). However, some problems can be associated with no-tillage management, principally reduced crop root growth due to surface soil compaction by agricultural machinery operated when soil moisture is too high (Collares et al., 2006).

Crop management systems can influence soil in terms of nutrient availability, the soil depth utilized by roots and the amount and quality of plant residues. These factors can alter not only the physical 
(Albuquerque et al., 1995) and chemical properties of the soil (Bayer and Mielniczuk, 1997) but also its microbial diversity and activity (Balota et al., 2004). The plant diversity of a production system exercises great influence on the structure of the microbial community of a soil, whether as a function of rhizospheric activity or of the amount and composition of organic $\mathrm{C}$ added to the system in the form of plant residues (Wieland et al., 2001). Because of these factors, cropping systems inevitably have impacts on soil processes, including fungistasis. Management practices, such as crop rotation (Mazzola and $\mathrm{Gu}$, 2002) and soil tillage, have the capacity to affect the microbial populations involved in the control of soil pathogens, thus introducing the possibility of manipulating fungistasis by applying appropriate agronomic techniques (Sipilä et al., 2012).

The study described in this paper evaluated fungistasis in a soil under different management systems designed to affect Fusarium graminearum, and also explored the relationship of this phytopathogen with the genetic profile of the bacterial community of the soil and the probable microbiological mechanisms involved in fungistasis.

\section{MATERIAL AND METHODS}

\section{Sampling and treatments}

The study was carried out in December 2010 utilizing a long-term soil management experiment of a Argissolo Vermelho distrófico típico (Embrapa, 2006) [Paleudult] which began in 1983 at the Agronomic Experimental Station of the Universidade Federal do Rio Grande do Sul in the southern Brazilian State of Rio Grande do Sul at 30 50' 52" S, $51^{\circ} 38^{\prime} 08^{\prime \prime}$ W. Climate in the region is subtropical with a hot humid summer of the Cfa fundamental type, according to the Köppen classification (Brasil, 1969).
We appraised two soil management systems (conventional tillage and no-tillage) which constituted the main plots, each of $15 \times 20 \mathrm{~m}\left(300 \mathrm{~m}^{2}\right)$, and three cropping systems (black oat (Avena strigosa Schreb) $+\operatorname{vetch}($ Vicia sativa L.)/maize (Zea mays L.) + cowpea (Vigna sinensis L.), black oat/maize, and vetch/maize) which constituted the split-plots, each of $5 \times 20 \mathrm{~m}\left(100 \mathrm{~m}^{2}\right)$. The main plots were subjected to the appropriate soil management system before the summer planting season - conventional tillage consisted of plowing plus two diskings, whereas for no-tillage management, seeds were sown on the residues of the previous crop without any additional soil preparation. All the winter crops used no-tillage management. The specific technical recommendations for each crop were used to select the crop variety, sowing density, soil fertility management, and crop treatment, except that there was no external nitrogen fertilizer input. On December 02, 2010, 30 days after the maize had germinated, a soil sampling auger was used to collect 15 random soil samples from the $0-7 \mathrm{~cm}$ layer of each subplot. All samples were passed through a $2 \mathrm{~mm}$ sieve and analyzed chemically using standard methods (Table 1). Subsamples for fungistasis and bacteriological analysis were stored at $4{ }^{\circ} \mathrm{C}$ for at most 10 days before analysis, and subsamples for molecular biology analyses were stored at $-4{ }^{\circ} \mathrm{C}$ until analysis.

\section{Soil fungistasis}

These experiments used a Fusarium graminearum isolate from the culture collection of the Universidade Federal do Rio Grande do Sul. To determine the effects of soil fungistasis on $F$. graminearum in the different management systems we used an in vitro assay (Ghini and Zarone, 2001) in which $50 \mathrm{~g}$ samples of chloroform-fumigated or unfumigated soil from the original soil samples were placed in sterilized Petri dishes, covered with $10 \mathrm{~mL}$ of sterilized water-agar which was allowed to rest, and then inoculated with a mycelial disk of yeast extract mannitol agar from a four-day, $23^{\circ} \mathrm{C} \mathrm{F}$. graminearum culture. The

Table 1. Chemical analysis of soil from different soil management and cropping systems

\begin{tabular}{lccccccccc}
\hline System(1) & $\mathbf{P}$ & $\mathbf{K}$ & $\mathbf{C l a y}$ & $\mathbf{O M}$ & $\mathbf{p H}\left(\mathbf{C a C l}_{2}\right)$ & $\mathbf{S M P}$ & $\mathbf{A l}^{3+}$ & $\mathbf{C a}^{2+}$ & $\mathbf{M g}^{2+}$ \\
\hline & \multicolumn{2}{c}{$\mathrm{mg} \mathrm{dm}^{-3}$} & & $\%$ & $\%$ & & & & $\mathrm{mmol}_{\mathrm{c}} \mathrm{dm}^{-3}$ \\
\cline { 2 - 7 } O/M (CT) & 15.0 & 152 & 31 & 1.7 & 5.2 & 5.9 & 3 & 21 \\
O/M (NT) & 53.0 & 214 & 26 & 2.4 & 5.6 & 6.0 & 0 & 25 & 14 \\
O +V/M+C (CT) & 42.9 & 154 & 31 & 2.4 & 5.1 & 5.7 & 5 & 20 & 14 \\
O +V/M+C (NT) & 23.9 & 207 & 23 & 3.6 & 5.1 & 5.7 & 3 & 28 & 15 \\
V/M (CT) & 3.8 & 132 & 33 & 2.0 & 4.7 & 5.5 & 8 & 19 & 8 \\
V/M (NT) & 26.1 & 155 & 26 & 3.1 & 4.8 & 5.5 & 5 & 20 & 16 \\
\hline
\end{tabular}

(1) O/M: black oat + maize; O+V/M+C: blak oat +vetch/maize +cowpea; V/M: vetch/maize; CT: conventional tillage; NT: No-tillage; OM: organic matter. $\mathrm{P}$ and K: extractor Mehlich-1; Ca and Mg: extractor $1 \mathrm{~mol} \mathrm{~L}^{-1} \mathrm{KCl}$. 
water-agar acted as an interface between the soil and $F$. graminearum. The plates were incubated in the dark at $23^{\circ} \mathrm{C}$ for 4 days and the radial growth of the fungi was measured. The percentage of fungistasis was calculated as follows:

Fungistasis $(\%)=\frac{\text { unfumigated diameter }- \text { fumigated diameter }}{\text { fumigated diameter }} \times 100$

A completely randomized experimental design and four replicates were used for each treatment. The data were subjected to contrast analysis at the $5 \%$ significance level.

\section{Ribosomal intergenic spacer analysis (RISA)}

Bacterial diversity of the soil under the different management and cropping systems was investigated using ribosomal intergenic spacer analysis (RISA), a technique based on variability in the size of the area between the $16 \mathrm{~S}$ and $23 \mathrm{~S}$ ribosome subunits. For each treatment, the genomic DNA of the soil microbial community was extracted from $300 \mathrm{mg}$ of soil using a Nucleo Spin ${ }^{\mathrm{TM}}$ soil kit (Macherey-Nagel, Bethlehem, PA, USA) according to manufacturer's instructions and the purified DNA was used for PCR-RISA. The $25 \mu \mathrm{L}$ amplification reaction contained $2.5 \mu \mathrm{L}$ of $10 \mathrm{x}$ PCR buffer, $1.5 \mu \mathrm{L}$ of $\mathrm{MgCl}, 11 \mu \mathrm{L}$ of DMSO, $2 \mu \mathrm{L}$ of DNA mold, $1.25 \mu \mathrm{L}$ of each of the oligonucleotide initiators SD-Bact-1522-bS-20 and LD-Bact-132-aA-18 (both at $20 \mathrm{mmol} \mathrm{L}^{-1}$ ), $0.25 \mu \mathrm{L}$ of a solution containing $0.25 \mathrm{mmol} \mathrm{L}^{-1}$ of each DNTP, $0.2 \mu \mathrm{L}$ of Taq polymerase, and sufficient ultrapure sterile water to complete the volume. Amplification was carried out according to the method of Fisher and Triplett (1999), with an initial denaturation cycle of $94^{\circ} \mathrm{C}$ for $2 \mathrm{~min}$, followed by 30 amplification cycles $\left(15 \mathrm{~s}\right.$ at $94^{\circ} \mathrm{C}, 15 \mathrm{~s}$ at $55^{\circ} \mathrm{C}$, and $45 \mathrm{~s}$ at $72^{\circ} \mathrm{C}$ ) and $72^{\circ} \mathrm{C}$ for $2 \mathrm{~min}$ before the final extension. The amplification products were subjected to polyacrylamide $(1.5 \% \mathrm{w} / \mathrm{v})$ electrophoresis using $1 \times$ TBE buffer and a constant voltage of $70 \mathrm{~V}$. The band profile was analyzed using the Bionumerics program, version 7 , and genetic similarity between treatments was evaluated with the Jaccard coefficient for group analysis.

\section{Isolation and sequencing of the $16 \mathrm{~S}$ rDNA region of the bacterial isolates}

The mechanisms of antagonism to $F$.graminearum were investigated using bacterial isolates obtained by serial dilution of the soil samples taken from each of the treatments; 20 bacterial isolates were obtained from colonies isolated from each of the treatments to produce a total of 120 isolates.

The bacterial isolates that showed antagonism to F. graminearum in the radial growth tests were identified to genus level using 16S rDNA fragment sequencing. For each isolate, bacterial genomic DNA was isolated using the Ultra Clean ${ }^{\mathrm{TM}}$ Kit (MO BIO Inc, Carlsbad, CA, USA) and $1.8 \mathrm{~mL}$ of a bacterial culture grown in liquid yeast extract medium according to manufacturer's instructions. The purity of each DNA sample was verified using $1 \mu$ of purified DNA agarose gel $(1 \% \mathrm{w} / \mathrm{v})$ electrophoresis Blue Green staining.

The bacterial genomic DNA of each isolate underwent PCR amplification of the $16 \mathrm{~S}$ rRNA gene using the oligonucleotide initiators U968 (AACGCGAAGAACCTTAC) and L1401 (CGGTGTGTACAAGACCC) (Felske et al., 1999) that amplify fragments of approximately $433 \mathrm{bp}$. The gene was sequenced using an automatic sequencer, the ABI-PRISM 3100 Genetic Analyzer (Applied Biosystems). The sequences obtained were identified to genus level using the Basic Local Alignment Search Tool (BLAST ${ }^{\circledR} ;$ http://blast.ncbi.nlm.nih.gov/Blast.cgi).

\section{Mechanisms of action}

The potential of the bacterial isolates to effect antibiosis against $F$. graminearum was determined using an adapted in vitro test (Shiomi et al., 2008). We grew $F$. graminearum on sterilized plates of yeast extract mannitol agar for 5 days at $23^{\circ} \mathrm{C}$ and removed a $1 \mathrm{~cm}$ diameter mycelial disk, which was placed in the center of a plate of the same medium. The soil bacteria isolates from each soil sample were pre-grown in pure culture in liquid yeast extract medium for three days at $28^{\circ} \mathrm{C}$. For each plate, four different pure cultures of soil bacteria were inoculated separately onto each quadrant adjacent to the mycelial disk. The plates were incubated at $23{ }^{\circ} \mathrm{C}$ for 5 days with a $12 \mathrm{~h}$ photoperiod, after which the diameter of any fungal inhibition halo was measured. Four replicates were made for each plate, and the mean diameter of the inhibition halo was calculated and compared using the Scott-Knott test at the $5 \%$ significance level.

Volatile compounds produced by soil bacteria can inhibit $F$. graminearum. With this in mind, we evaluated the capacity of our bacterial isolates to produce such compounds. This evaluation was made for each soil bacteria isolate by the inverted plate method (Romeiro, 2007), which consists of using the bottoms of two Petri dishes containing sterilized yeast extract mannitol agar, one containing an $F$. graminearum mycelial disk and the other a soil bacterial isolate. The two plate bottoms were inverted over each other and sealed with PVC film and then incubated, with the mycelial disk in the uppermost plate, at $23{ }^{\circ} \mathrm{C}$ for 4 days, after which the diameter of the $F$. graminearum colony was measured. Four replicates were made for each bacterial isolate and compared to a control containing only an $F$. graminearum mycelial disk. Average $F$. graminearum radial growth was measured and compared using the test Scott-Knott test at the $5 \%$ significance level.

Siderophore production was evaluated for the soil bacteria isolates that demonstrated in vitro 
potential for $F$. graminearum inhibition. Each isolate tested was grown in sterilized liquid yeast extract mannitol medium at $\mathrm{C}$ for $72 \mathrm{~h}$ under constant shaking at $128 \mathrm{rev} \mathrm{min}^{-1}$. After incubation, $10 \mu \mathrm{L}$ of the bacterial suspension was inoculated onto Petri dishes containing iron-deficient King's B medium with the blue dye chrome azurol S (CAS), and the plates were incubated for 5 days at $28^{\circ} \mathrm{C}$. Siderophore producing isolates created a yellowish halo around the bacterial colony, indicating that siderophores produced by the isolate sequestered iron chelated to the dye causing it to change color (Schwyn and Neilands, 1987).

\section{RESULTS AND DISCUSSION}

\section{Determination of soil fungistasis}

The analysis of soil fungistasis in the different management systems showed no interaction between the soil management systems and the cropping systems, although significant differences were observed in the isolated effects. For all the treatments, growth of $F$. graminearum was greatest for the soil samples fumigated with chloroform, for which the fungus showed a mean growth of $5.9 \mathrm{~cm}$, compared to unfumigated soil with a mean growth of $0.7 \mathrm{~cm}$. These results were similar to those obtained by Ghini and Zarone (2001), who reported that the relative growth of a pathogen in fumigated soil was greater for the soil samples that had the greatest antagonistic potential, something which was also seen in our study. Our results indicate the participation of the soil microbial community in the reduction of $F$. graminearum development, indicating that a reduction in the activity of the native soil microbiota due to chloroform fumigation may lead to greater development of this plant pathogenic fungus.

Fungistasis was higher for soil under no-tillage management as compared with conventional tillage (Table 2). Conservation soil management systems such as no-tillage produce greater competition between soil microorganisms and a reduction in the pathogen load (Garbeva et al., 2011) of the upper soil layer, which has the highest density of root activity (Sturz et al., 1997). Increased competition between soil microorganisms probably occurs because, under no-tillage management, crop residues remain on the soil surface and the levels of organic matter $(\mathrm{OM})$ incorporated into the soil are stable. However, in conventional tillage, plowing and harrowing break up $\mathrm{OM}$ and force it into more intimate contact with soil particles, which not only assists in dispersing aggregated OM but also exposes the most protected OM fractions to microbial degradation (Garbeva et al., 2011). Such factors, along with a lack of soil cover, result in decreased levels of
OM in conventionally tilled soil (Lee et al., 1993), which shows reduced microbial activity and soil suppression capacity.

The different cropping systems showed significant differences in soil fungistasis, with fungistasis against $F$. graminearum being higher in the cropping systems incorporating the legumes vetch and cowpea (Table 2). It has been reported that an increase in the complexity of cultivations due to the employment of a larger number of plant species and the inclusion of legumes in the system results in increased OM in the soil structure (Janvier et al., 2007), and it has also been shown that low availability of soil $\mathrm{N}$ is the main factor imitating increased $\mathrm{OM}$ in degraded soils (Mielniczuk et al., 2003). The addition of the legume consociates to the cropping systems increased production of biological $\mathrm{N}_{2}$ fixation and, consequently, plant biomass, thus favoring the accumulation of fixed $\mathrm{C}$ in the soil as compared to the cropping systems without legumes. This effect was particularly evident in our experiments because we did not apply inorganic $\mathrm{N}$ to our plots; biological $\mathrm{N}_{2}$ fixation was the only source of $\mathrm{N}$.

Other studies support our findings. Garbeva et al. (2006) evaluated fungistasis against plant pathogenic Rhizoctonia solani in different soil management systems and found that conservationist management increased fungistasis. Likewise, Sipilä et al. (2012) identified a positive correlation between no-tillage management and soil suppression of the pathogen Fusarium culmorum, concluding that soil management strategies have strong influences on soil microbiological processes, including suppression. It thus seems that the employment of suitable soil management and cropping systems favors the potential suppressive properties of some soils.

Table 2. Mean fungistasis against Fusarium graminearum and mean contrasts between different soil management systems (conventional tillage, CT and no-tillage, NT) and cropping systems (black oat (Avena strigosa) + vetch (Vicia sativa)/maize (Zea mays) + cowpea (Vigna sinensis), black oat/maize, and vetch/maize)

\begin{tabular}{lccc}
\hline System $^{(1)}$ & Mean & Contrast & Estimate \\
\hline & $\%$ & & $\%$ \\
$\mathrm{CT}$ & 81.1 & $(\mathrm{NT}) \times(\mathrm{CT})$ & $13.33^{*}$ \\
$\mathrm{NT}$ & 94.4 & $(\mathrm{O}+\mathrm{V} / \mathrm{M}+\mathrm{C})+(\mathrm{V} / \mathrm{M}) \times(\mathrm{O} / \mathrm{M})$ & $10.30^{*}$ \\
$(\mathrm{O}+\mathrm{V} / \mathrm{M}+\mathrm{C})$ & 97.7 & $(\mathrm{O}+\mathrm{V} / \mathrm{M}+\mathrm{C}) \times(\mathrm{V} / \mathrm{M})$ & $13.01^{*}$ \\
$(\mathrm{~V} / \mathrm{M})$ & 84.6 & $(\mathrm{~V} / \mathrm{M}) \times(\mathrm{O} / \mathrm{M})$ & $3.80^{\mathrm{ns}}$ \\
$(\mathrm{O} / \mathrm{M})$ & 80.8 & $(\mathrm{O} / \mathrm{V}+\mathrm{M} / \mathrm{C}) \times(\mathrm{O} / \mathrm{M})$ & $16.81^{*}$ \\
\hline
\end{tabular}

(1) O: black oat; V: vetch; M: maize; and C: cowpea. ns and *: not-significant and significant at $5 \%$, respectively. 


\section{RISA analysis}

Our RISA analysis indicated that both soil management and cropping systems influenced the genetic profile of the soil prokaryotes obtained in our experiments. The dendrogram generated by subjecting the banding patterns to cluster analysis (Figure 1) produced two main groups, one containing the isolates from no-tillage management and the other containing the isolates from conventional tillage management. Each group contained two subdivisions, one containing the isolates from the cropping systems containing legumes (black oat + vetch /maize + cowpea, and vetch/maize), and the other containing only the grasses (Poaceae) - black oat and maize.

The RISA genetic profile of the soil prokaryotes isolated from the different soil management and cropping systems was also related to soil fungistasis against $F$. graminearum, with no-tillage management of cropping systems containing legumes showing the highest levels of fungistasis. Similar results were reported by Rimé et al. (2003), who used RISA to evaluate the diversity of the prokaryotic community of some soils and found that it was possible to statistically distinguish suppressive and non-suppressive soils.

\section{Bacterial isolate identification using 16S rDNA}

We obtained 120 bacterial isolates, 20 from each of the six treatments, 33 of which inhibited the growth of $F$. graminearum. Sequencing 16S rRNA fragments from each of the 33 isolates identified

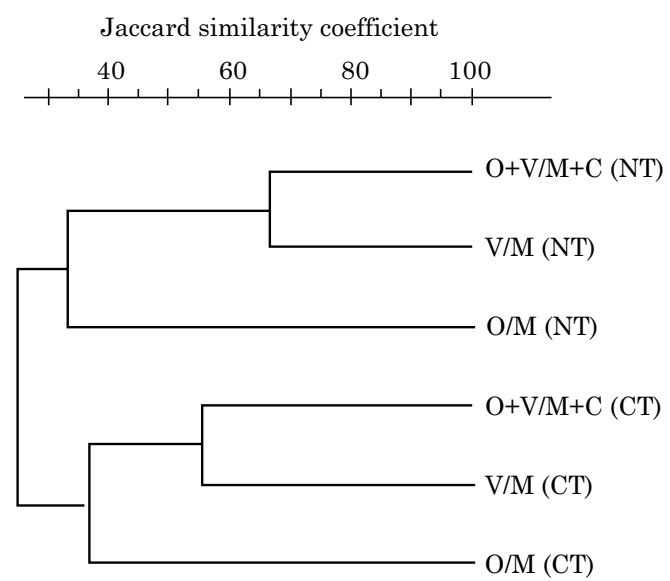

Figure 1. Dendrogram of the Jaccard similarity coefficient for bacterial isolates obtained from an Argissolo Vermelho distrófico (Paleudult) under different soil management (conventional tillage, CT and no-tillage, NT) and cropping systems (black oat (Avena strigosa) + vetch (Vicia sativa)/maize (Zea mays) + cowpea (Vigna sinensis), black oat/maize, and vetch/maize). O: black oat; V: vetch; M: maize, and C: cowpea. eight bacterial genera: Burkholderia (48\%), Bacillus (18\%), Streptomyces (12\%), Paenibacillus (6\%), Rhizobium (6 \%), Pseudomonas (3\%), Dyella (3\%), and Mesorhizobium (3 \%). Benítez et al. (2007) used molecular techniques to identify soil bacterial groups linked to antagonism to pathogenic oomycetes, which were also observed in our experiments. Similarly, Yin et al. (2013) reported the occurrence of the prokaryotic bacterial genera Mesorhizobium, Burkholderia, and Dyella in the rhizosphere of healthy wheat plants during experiments designed to evaluate soil antagonism to Rhizoctonia solani.

There was no predominance of any particular genus in any of the management or cropping systems examined by us, indicating that soil bacteria with antagonistic potential occur in soils regardless of the management systems used.

\section{Mechanisms of action}

\section{Antibiosis tests}

All the 120 isolates were tested in vitro for potential antagonism to $F$. graminearum; 34 (27.5\%) were identified as showing some level of inhibition (Table 3). Statistical analysis indicated that at least five isolates showed potential against $F$. graminearum; interestingly, none of these five isolates came from the black oat/maize cropping system under conventional soil management, the management system which showed the smallest fungistasis effect.

We found that $45.4 \%$ of the 34 isolates showing antagonism came from no-tillage management and $54.5 \%$ from conventional tillage management. Furthermore, there was no marked difference between the following cropping systems: black oat + maize (39.4\% of isolates), black oat + vetch/maize + cowpea (33\% of isolates) and vetch/maize (27.3\% of isolates). There thus appeared to be no clear relationship between the antagonist potential of an isolate obtained from a particular soil management or cropping system and soil fungistasis. These results seem to be at variance with those obtained by Adesina et al. (2007), who reported that a larger proportion of antagonistic isolates came from soil samples known to be more fungistatic. However, since all our treatments showed some potential fungistasis and bacteria with antagonistic properties, our results do agree with the work of Baker and Cook (1974), who argued that all soils possesses some control potential.

In the test of volatile compounds, $F$. graminearum was inhibited by only two isolates, a Paenibacillus sp isolated from soil sample 16 from the black oat $(\mathrm{O})+\operatorname{vetch}(\mathrm{V}) /$ maize $(\mathrm{M})+$ cowpea $(\mathrm{C})$ cropping system under no-tillage (NT) management (isolate $\mathrm{O}+\mathrm{V} / \mathrm{M}+\mathrm{C}(\mathrm{NT})-16)$ and a Streptomyces sp. (isolate $\mathrm{O}+\mathrm{V} / \mathrm{M}+\mathrm{C}(\mathrm{NT})-23$ ) isolated from soil sample 23 from the same cropping and soil management system. It is interesting to note that both these isolates 
Table 3. Mechanisms of inhibition of Fusarium graminearum by bacterial isolates obtained from soil under different soil management practices

\begin{tabular}{|c|c|c|c|c|}
\hline Isolate(1) & Genus & Inhibition halo & Inhibition by bacterial volatile compound & Siderophore production \\
\hline & & & $\mathrm{cm}$ & \\
\hline $\mathrm{V} / \mathrm{M}(\mathrm{CT})-3$ & Bacillus sp. & $1.30 \mathrm{a}$ & $3.25 \mathrm{~b}$ & + \\
\hline $\mathrm{O}+\mathrm{V} / \mathrm{M}+\mathrm{C}(\mathrm{NT})-14$ & Burkholderia sp. & $1.20 \mathrm{a}$ & $2.88 \mathrm{~b}$ & + \\
\hline $\mathrm{V} / \mathrm{M}(\mathrm{CT})-4$ & Streptomyces sp. & $1.00 \mathrm{a}$ & $3.25 \mathrm{~b}$ & - \\
\hline $\mathrm{A} / \mathrm{M}(\mathrm{NT})-14$ & Burkholderia sp. & $0.97 \mathrm{a}$ & $3.45 \mathrm{~b}$ & + \\
\hline $\mathrm{O}+\mathrm{V} / \mathrm{M}+\mathrm{C}(\mathrm{NT})-9$ & Bacillus sp. & $0.93 \mathrm{a}$ & $3.28 \mathrm{~b}$ & + \\
\hline $\mathrm{O}+\mathrm{V} / \mathrm{M}+\mathrm{C}(\mathrm{NT})-10$ & Burkholderia sp. & $0.90 \mathrm{~b}$ & $3.50 \mathrm{~b}$ & + \\
\hline $\mathrm{O}+\mathrm{V} / \mathrm{M}+\mathrm{C}(\mathrm{NT})-16$ & Paenibacillus sp. & $0.87 \mathrm{~b}$ & $1.37 \mathrm{a}$ & + \\
\hline $\mathrm{V} / \mathrm{M}(\mathrm{CT})-5$ & Bacillus sp. & $0.87 \mathrm{~b}$ & $3.37 \mathrm{~b}$ & + \\
\hline $\mathrm{O} / \mathrm{M}(\mathrm{NT})-26$ & Bacillus sp. & $0.83 \mathrm{~b}$ & $3.62 \mathrm{~b}$ & + \\
\hline $\mathrm{O}+\mathrm{V} / \mathrm{M}+\mathrm{C}(\mathrm{CT})-12$ & Burkholderia sp. & $0.83 \mathrm{~b}$ & $3.21 \mathrm{~b}$ & + \\
\hline V/M (CT)-10 & Rhizobium sp. & $0.80 \mathrm{~b}$ & $4.10 \mathrm{~b}$ & + \\
\hline V/M (NT)-22 & Rhizobium sp. & $0.80 \mathrm{~b}$ & $3.25 \mathrm{~b}$ & + \\
\hline $\mathrm{O} / \mathrm{M}(\mathrm{NT})-24$ & Burkholderia sp. & $0.77 \mathrm{~b}$ & $3.12 \mathrm{~b}$ & + \\
\hline $\mathrm{O}+\mathrm{V} / \mathrm{M}+\mathrm{C}(\mathrm{NT})-23$ & Streptomyces sp. & $0.67 \mathrm{~b}$ & $2.00 \mathrm{a}$ & - \\
\hline $\mathrm{O} / \mathrm{M}(\mathrm{NT})-22$ & Burkholderia sp. & $0.67 \mathrm{~b}$ & $2.87 \mathrm{~b}$ & + \\
\hline $\mathrm{O}+\mathrm{V} / \mathrm{M}+\mathrm{C}(\mathrm{NT})-17$ & Pseudomonas sp. & $0.60 \mathrm{c}$ & $3.15 \mathrm{~b}$ & + \\
\hline $\mathrm{O} / \mathrm{M}(\mathrm{CT})-17$ & Burkholderia sp. & $0.60 \mathrm{c}$ & $3.36 \mathrm{~b}$ & - \\
\hline $\mathrm{O}+\mathrm{V} / \mathrm{M}+\mathrm{C}(\mathrm{CT})-1$ & Burkholderia sp. & $0.53 \mathrm{c}$ & $3.27 \mathrm{~b}$ & - \\
\hline V/M (NT)-7 & Burkholderia sp. & $0.53 \mathrm{c}$ & $3.12 \mathrm{~b}$ & + \\
\hline $\mathrm{O} / \mathrm{M}(\mathrm{CT})-25$ & Burkholderia sp. & $0.50 \mathrm{c}$ & $3.50 \mathrm{~b}$ & - \\
\hline $\mathrm{O} / \mathrm{M}(\mathrm{CT})-23$ & Streptomyces sp. & $0.50 \mathrm{c}$ & $3.28 \mathrm{~b}$ & + \\
\hline V/M (NT)-11 & Burkholderia sp. & $0.47 \mathrm{c}$ & $3.57 \mathrm{~b}$ & - \\
\hline $\mathrm{O}+\mathrm{V} / \mathrm{M}+\mathrm{C}(\mathrm{CT})-4$ & Burkholderia sp. & $0.40 \mathrm{c}$ & $3.47 \mathrm{~b}$ & - \\
\hline $\mathrm{O} / \mathrm{M}(\mathrm{CT})-10$ & Burkholderia sp. & $0.33 \mathrm{~d}$ & $4.38 \mathrm{~b}$ & - \\
\hline V/M (NT)-12 & Bacillus sp. & $0.33 \mathrm{~d}$ & $3.25 \mathrm{~b}$ & + \\
\hline $\mathrm{O} / \mathrm{M}(\mathrm{CT})-10$ & Streptomyces sp. & $0.33 \mathrm{~d}$ & $3.55 \mathrm{~b}$ & - \\
\hline $\mathrm{O} / \mathrm{M}(\mathrm{CT})-21$ & Dyella sp. & $0.27 \mathrm{~d}$ & $3.74 \mathrm{~b}$ & - \\
\hline $\mathrm{O}+\mathrm{V} / \mathrm{M}+\mathrm{C}(\mathrm{CT})-26$ & Bacillus sp. & $0.23 \mathrm{~d}$ & $3.85 \mathrm{~b}$ & + \\
\hline $\mathrm{O}+\mathrm{V} / \mathrm{M}+\mathrm{C}(\mathrm{CT})-23$ & Burkholderia sp. & $0.13 \mathrm{~d}$ & $3.50 \mathrm{~b}$ & + \\
\hline V/M (NT)-12 & Mesorhizobium sp. & $0.20 \mathrm{~d}$ & $3.81 \mathrm{~b}$ & + \\
\hline $\mathrm{O}+\mathrm{V} / \mathrm{M}+\mathrm{C}(\mathrm{CT})-2$ & Burkholderia sp. & $0.20 \mathrm{~d}$ & $3.62 \mathrm{~b}$ & + \\
\hline $\mathrm{O} / \mathrm{M}(\mathrm{CT})-15$ & Burkholderia sp. & $0.20 \mathrm{~d}$ & $3.81 \mathrm{~b}$ & - \\
\hline $\mathrm{O}+\mathrm{V} / \mathrm{M}+\mathrm{C}(\mathrm{CT})-23$ & Paenibacillus sp. & $0.20 \mathrm{~d}$ & $3.24 \mathrm{~b}$ & - \\
\hline Control & - & & $4.38 \mathrm{~b}$ & \\
\hline
\end{tabular}

(1) NT: no-tillage; CT: conventional tillage; BO: black oat; V: vetch; M: maize, and C: cowpea. The numbers at the end of the source code indicate from which of the 15 soil samples the replicate was isolated. Mean values followed by different lowercase letters in the same column differ significantly by the Scott-Knott test at the $5 \%$.

came from the same cropping and soil management system and that this system also showed the highest levels of fungistasis.

Although other studies have shown that from 30 to $60 \%$ of isolates of soil bacteria can produce volatile fungal inhibitors (Zou et al., 2007) and that these bacteria come from very diverse genera, including
Bacillus, Micrococcus, Rhizobium, and Xanthomonas (Kai et al., 2007; Zou et al., 2007), this was not observed in our experiments. Hartmann et al. (2009) pointed out that the inhibitory capacity of a compound in the soil will depend not only on its specific biochemical effects on a pathogen but also on the ability of the compound to diffuse in the culture media or soil. 


\section{Siderophore production}

We found that for the isolates antagonistic to $F$. graminearum, 21 of the 33 isolates tested (63.6 \%) also produced siderophores, most of these isolates being Burkholderia species. Adesina et al. (2007) also reported that a high proportion (83\%) of bacterial isolates antagonistic to Fusarium oxysporum were siderophore positive, while Arruda et al. (2013), in a study of bacterial promoters of maize growth, also noted that a large proportion of siderophore producing isolates were Burkholderia.

Of the ten most antagonistic isolates obtained in our study, we found only one that did not produce siderophores, whereas half of the ten least antagonistic isolates produced no siderophores. Siderophore production is considered to be one of the main soil fungistasis mechanisms, since production of these iron sequestering compounds confers a major selective advantage in terms of competition for available environmental iron (Arora et al., 2001). This mechanism was observed by De Boer et al. (2003) while working with $F$. oxysporum radish wilt. These authors found that siderophores were produced by the Pseudomonas putida isolate WCS358, although, as for antibiosis, there was no apparent relationship between the management systems and the siderophore producing bacterial isolates.

\section{CONCLUSIONS}

Soil fungistasis against $F$. graminearum is influenced by the soil management system and by the soil microbial community.

In general, the addition of a legume crop to the cropping system increased soil fungistasis.

Soil under no-tillage management showed higher levels of fungistasis as compared to conventional tillage.

Different management systems result in the detection of soil prokaryotes with different genetic profiles, and there are similarities between the most antagonistic systems.

Antibiosis and siderophore production were the mechanisms contributing most to soil fungistasis.

\section{REFERENCES}

Adesina MF, Lembke A, Costa R, Speksnijder A, Smalla K. Screening of bacterial isolates from various European soils for in vitro antagonistic activity towards Rhizoctnoia solani and Fusarium oxysporum: Site-dependent composition and diversity revealed. Soil Biol Biochem. 2007;39:2818-28.

Albuquerque JA, Reinert DJ, Fiorin JE, Ruedell J, Petrere C, Fontinelli F. Rotação de culturas e sistemas de manejo do solo:
Efeito sobre a forma da estrutura do solo ao final de sete anos. $\mathrm{R}$ Bras Ci Solo. 1995;19:115-9.

Arora NK, Kang SC, Maheshwari DK. Isolation of siderophoreproducing strains of Rhizobium meliloti and their biocontrol potential against Macrophomina phaseolina that causes charcoal rot of groundnut. Curr Sci. 2001;81:673-7.

Arruda L, Beneduzi A, Martins A, Lisboa B, Lopes C, Bertolo F, et al. Screening of rhizobacteria isolated from maize (Zea mays L.) in Rio Grande do Sul State (South Brazil) and analysis of their potential to improve plant growth. Appl Soil Ecol. 2013;63:15-22.

Balota EL, Colozzi Filho A, Andrade DS, Dick RP. Long-term tillage and crop rotation effects on microbial biomass and $\mathrm{C}$ and $\mathrm{N}$ mineralization in a Brazilian Oxisol. Soil Till Res. 2004;77:137-45.

Baker KF, Cook RJ. Biological control of plant pathogens. San Francisco: American Phytopathology Society; 1974.

Bayer C, Mielniczuk J. Características químicas do solo afetadas por métodos de preparo e sistemas de cultura. R Bras Ci Solo. 1997;21:235-9.

Benítez M, Tustas FB, Rotenberg D, Kleinhenz MD, Cardina J, Stinner D, Miller AS, Gardener BB. Multiple statistical approaches of community fingerprint data reveal bacterial populations associated with general disease suppression arising from the application of different organic field management strategies. Soil Biol Biochem. 2007;39:2289-301.

Brasil. Ministério da Agricultura. Escritório de meteorologia. Atlas climatológico do Brasil [atlas]. Rio de Janeiro; 1969.

Collares GL, Reinert DJ, Reichert JM, Kaiser DR. Qualidade física do solo na produtividade da cultura do feijoeiro num Argissolo. Pesq Agropec Bras. 2006;41:1663-74.

De Boer M, Bom P, Kindt F, Keurentjes JJB, Van Der Sluis I, Van Loon LC, Bakker PHM. Control of Fusarium wilt radish by combining Pseudomonas putida strains that have different disease-suppressive mechanisms. Phytopathology. 2003;93:626-32.

Derpsch R, Friedrich T, Kassam A, Hongwen L. Current status of no-till farming in the world and some of its main benefits. Int. J Agric Biol Eng. 2010;3:1-25.

Empresa Brasileira de Pesquisa Agropecuária - Embrapa. Sistema brasileiro de classificação de solos. Brasília, DF: 2006.

Felske A, Wolterink A, Van Lis R, De Vos WM, Akkermans ADL. Searching of predominant soil bacteria $16 \mathrm{~S}$ rDNA cloning versus strain cultivation. FEMS Microbiol Ecol. 1999;30:37-45.

Fisher MM, Triplett EW. Automated approach for ribosomal intergenic spacer analysis of microbial diversity and its application to freshwater bacterial communities. Appl Environ Microbiol. 1999;65:4630-6.

Garbeva P, Gera HWH, Termorshuizen AJ, Kowalchuk GA, De Boer W. Fungistasis and general soil biostasis - a new synthesis. Soil Biol Biochem. 2011;43:469-77.

Garbeva P, Postma J, Van Veen JA, Van Elsas JD. Effect of aboveground plant species on soil microbial community structure and its impact on suppression of Rhizoctonia solani AG3. Environ Microbiol. 2006;8:233-46.

Ghini R, Zaroni MMH. Relação entre coberturas vegetais e supressividade de solos a Rhizoctonia solani. Fitopatol Bras. 2001;26:10-5. 
Hadar Y, Papadopoulou KK. Suppressive compost: microbial ecology links between abiotic environments and healthy plants. Ann Rev Phytopathol. 2012;50:133-53.

Hartmann A, Schimid M, Van Tuinen D, Berg G. Plant-driven selection of microbes. Plant Soil. 2009;321:235-57.

Jantalia CP, Alves BJR, Zotarelli L, Boddley RMB, Urquiaga S. Mudanças no estoque de $\mathrm{C}$ do solo em áreas de produção de grãos: avaliação do impacto do manejo de solo. In: Alves BJR, Urquiaga S, Aita C, Boddey RM, Jantalia CP, Camargo FAO, editores. Manejo de sistemas agrícolas: Impacto no sequestro de $\mathrm{C}$ e nas emissões de gases de efeito estufa. Porto Alegre: Genesis; 2006. p.35-58.

Janvier C, Villeneuve F, Alabouvette C, Edel-Hermann V, Mateille T, Steinberg C. Soil health through soil disease suppression: Which strategy from descriptors to indicators? Soil Biol Biochem. 2007;39:1-23.

Kai M, Effmert U, Berg G, Piechulla B. Volatiles of bacterial antagonists inhibit mycelial growth of the plant pathogen Rhizoctonia solani. Arch. Microbiol. 2007;187:351-60.

Lee JJ, Phillips DL, Liu R. The effect of trends in tillage practices on erosion and carbon content of soils in the US corn belt. Water Air Soil Pollut. 1993;70:389-401.

Mazzola M, Gu YH. Wheat genotype-specific induction of soil microbial communities suppressive to Rhizoctonia solani AG 5 and AG 8. Phytopathology. 2002;92:1300-7.

Mielniczuk J, Bayer C, Vezzani FM, Lovato T, Fernandes FF, Debarba L. Manejo de solo e culturas e sua relação com estoques de carbono e nitrogênio do solo. In: Curi N, Marques JJ, Guilherme LRG, Lima JM, Lopes AS, Alvarez V VH, editores. Tópicos em ciência do solo. Viçosa, MG: Sociedade Brasileira de Ciência do Solo; 2003. v.3, p.209-248.

Peters RD, Sturz AV, Carter MR, Sanderson JB. Developing disease-suppressive soils through crop rotation and tillage management practices. Soil Till Res. 2003;72:181-92.
Rimé D, Nazaret S, Gourbiere F, Cadet P, Moenne-Loccoz Y. Comparison of sandy soils suppressive or conducive to ectoparasitic nematode damage on sugarcane. Phytopathology. 2003;93:1437-44.

Romeiro RS. Controle biológico de enfermidades de plantas fundamentos. Viçosa, MG: Editora UFV; 2007.

Schwyn B, Neilands JB. Universal chemical assay for the detection of siderophores. Anal Biochem. 1987;160:47-56.

Shiomi HF, Melo IS, Minhoni MTA. Seleção de bactérias endofíticas com ação antagônicas a fitopatógenos. Sci Agrár. 2008;9:535-8.

Sipilä TP, Yrjälä K, Alakukku L, Palojärvib A. Cross-site soil microbial communities under tillage regimes: Fungistasis and microbial biomarkers. Appl Environ Microbiol. 2012;78:8191-201.

Sturz AV, Carter MR, Johnston HW. A review of plant disease, pathogen interactions and microbial antagonism under conservation tillage in temperate humid agriculture. Soil Till Res. 1997;41:169-89.

Weller M, Raaijmakers JM, Gardener BB, Thomashow LS. Microbial populations responsible for specific soil suppressiveness to plant pathogens. Ann Rev Phytopathol. 2002;40:309-48.

Wieland G, Neumann R, Backhaus H. Variation of microbial communities in soil, rhizosphere, and rhizoplane in response to crop species, soil type, and crop development. Appl Environ Microbiol. 2001;67:5849-54.

Yin C, Hulbert SH, Schroeder KL, Mavrodi O, Mavrodi D, Dhingra A, Paulit TC. The role of bacterial communities in the natural suppression of Rhizoctonia bare patch of wheat (Triticum aestivum L.). Appl Environ Microbiol. 2013;79:7428-38.

Zou CS, Mo MH, Gu YQ, Zhou JP, Zhang KQ. Possible contributions of volatile-producing bacteria to soil fungistasis. Soil Biol Biochem. 2007;39:2371-9. 